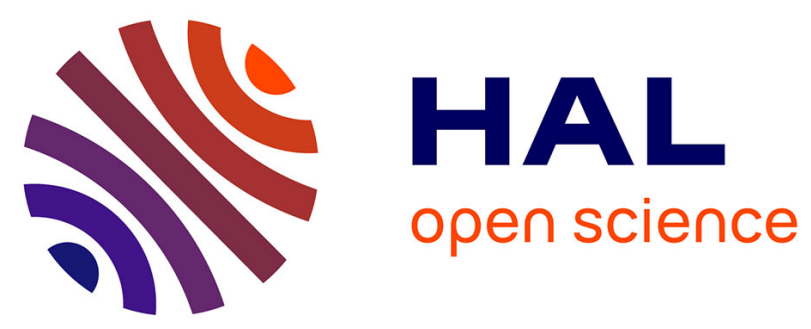

\title{
Modelling the influence of palmitic, palmitoleic, stearic and oleic acids on apparent heat resistance of spores of Bacillus cereus NTCC 11145 and Clostridium sporogenes Pasteur 79.3
}

Brice Mvou Lekogo, Louis Coroller, Anne Gabrielle Mathot, Pierre Mafart, Ivan Leguérinel

\section{To cite this version:}

Brice Mvou Lekogo, Louis Coroller, Anne Gabrielle Mathot, Pierre Mafart, Ivan Leguérinel. Modelling the influence of palmitic, palmitoleic, stearic and oleic acids on apparent heat resistance of spores of Bacillus cereus NTCC 11145 and Clostridium sporogenes Pasteur 79.3. International Journal of Food Microbiology, 2010, pp.242-247. hal-00654177

\section{HAL Id: hal-00654177 https://hal.univ-brest.fr/hal-00654177}

Submitted on 21 Dec 2011

HAL is a multi-disciplinary open access archive for the deposit and dissemination of scientific research documents, whether they are published or not. The documents may come from teaching and research institutions in France or abroad, or from public or private research centers.
L'archive ouverte pluridisciplinaire $\mathbf{H A L}$, est destinée au dépôt et à la diffusion de documents scientifiques de niveau recherche, publiés ou non, émanant des établissements d'enseignement et de recherche français ou étrangers, des laboratoires publics ou privés. 
1 Modelling the influence of palmitic, palmitoleic, stearic and oleic acids on apparent heat

2 resistance of spores of Bacillus cereus NTCC 11145 and Clostridium Sporogenes Pasteur

$3 \quad 79.3$.

4 Brice Mvou Lekogo ${ }^{1,2}$, Louis Coroller ${ }^{1,2}$, Anne Gabrielle Mathot ${ }^{1,2}$, Pierre Mafart ${ }^{1,2}$ and Ivan

5 Leguerinel $^{1,2^{*}}$

6

$7 \quad{ }^{1)}$ Université Européenne de Bretagne, France

$8 \quad{ }^{2)}$ Université de Brest, EA3882 Laboratoire Universitaire de Biodiversité et Ecologie

9 Microbienne, UMT 08.3 PHYSI'Opt, 6 rue de l’Université, 29000 Quimper, France.

10

$11{ }^{*}$ Corresponding author:

12 E-mail address: guerinel@univ-brest.fr

13

14 
Heat resistance of spores is affected by many factors such as temperature, $\mathrm{pH}$, water activity (aw) and others. Previous studies have reported that free fatty acids can affect the germination and growth of bacterial spores. In this study, we investigated the influence of free fatty acids in heating medium or in recovery medium on the heat resistance of spores of Bacillus cereus NTCC 11145 and Clostridium sporogenes Pasteur 79.3. Four free fatty acids were studied: palmitic, palmitoleic, stearic and oleic acid. During thermal treatments, the impact of these FFA in heating media was generally low, but the presence of free fatty acids in the recovery medium highly decreases bacterial spore apparent heat resistance, particularly with unsaturated fatty acids. A mathematical model was developed to describe and quantify the influence of free fatty acids in recovery media on the D-values. The z' ${ }_{\text {FFA }}$ parameter values which quantify the impact of free fatty acids were determined. The variation of this parameter value according to the free fatty acid type was compared with MIC value variation given in the literature. The model enables the decrease in D-values in the presence of free fatty acids to be estimated. The high concentrations of free fatty acids in liver or canned duck may explain the microbial stability with low sterilization values applied.

Key words: free fatty acids, bacterial spores, heat resistance, recovery medium. 


\section{Introduction}

Free fatty acids are a large group of non toxic compounds which present antimicrobial activity. It is well known that soaps composed of free fatty acid salt have a bactericidal effect. The bactericidal effect of free fatty acids has been extensively investigated and presented by Nieman (1954). More recently Kabara (1978) provided and analysed minimal inhibitory concentration values of saturated and unsaturated fatty acids for vegetative cells of pathogenic bacteria. For long chain fatty acids, the influence of free fatty acids varied according to acid type but did not correlate with carbon chain length. However, the carbon chain degree of unsaturation greatly influenced the MIC values.

The application of the bactericidal effect of fatty acids, given in the literature, mainly concerns soaps and the cosmetics industry. More recently, studies concerning the influence of free fatty acids on pathogens have examined food products. These studies focus on pathogens such as Salmonella, Listeria and Staphylococcus. However some spore-forming species have been studied such as Bacillus cereus (Ababouch et al., 1994; Lee et al., 2002), Bacillus subtilis (Tsuchido et al., 1992), Clostridium botulinum (Grecz et al., 1959) and Clostridium perfringens (Skřivanova et al., 2005).

In foods, free fatty acid concentrations are low, however in some foods containing fats and natural oils their concentrations are sufficient to affect bacterial growth. Free fatty acids in food can be considered as a hurdle usable for food preservation. In compliance with Leistner's concept (2000), this hurdle can be associated with other stresses such as temperature during heat treatment. The combination of heat treatment with $\mathrm{pH}$, water activity or acids on bacterial heat resistance have been studied, modelled and presented in different publications (Blackburn et al., 1997; Coroller et al., 2001; Couvert et al., 1999; Davey, 1993; Juneja and Eblen, 1999; Leguérinel et al., 2005). These combinations affect surviving bacteria in two stages: during heat treatment and during recovery. In these publications, a Bigelow- 
like model and $\mathrm{z}$ parameters were developed to quantify the impact of these environmental factors on the D-values.

Few studies quantify the influence of free fatty acids during heat treatment on bacterial spores. Tremoulet et al. (2002) observed for different free fatty acids (C16:0, C16:1, C18:1, C18:2 and C18:3) in heating media that their increasing concentration decreased the D-value for Geobacillus stearothermophilus. Concerning the presence of free fatty acids in recovery media following heat treatment Ababouch et al. (1994) have observed some influences.

The aim of this study was to quantify and model the influence of the concentration of palmitic acid (C16:0), palmitoleic acid (C16:1), stearic acid (C18:0) and oleic acid (C18:1), major free fatty acids in food, in heating and recovery media for B. cereus and C. sporogenes spores.

Material and methods

\subsection{Microorganism and spore production}

Spores of B. cereus NTCC11145 were obtained as follows: cells were precultivated at $37^{\circ} \mathrm{C}$ for $24 \mathrm{~h}$ in Brain Heart Infusion broth (Difco). The preculture was used to inoculate nutrient agar plates (Biokar Diagnostics BK021) to which $40 \mathrm{mg} / \mathrm{l}$ of $\mathrm{MnSO}_{4}$ and $100 \mathrm{mg} / \mathrm{l}$ of $\mathrm{CaCl}_{2}$ were added to the surface. The plates were incubated at $37^{\circ} \mathrm{C}$ for 5 days. Spores were then collected by scraping the surface of the agar. They were then suspended in sterile distilled water and washed three times by centrifugation (10,000 $\mathrm{g}$ for $15 \mathrm{~min}$ ) (Bioblock Scientific, model Sigma 3K30). The final suspension ( approximately $10^{10}$ spores/ml) was finally distributed into sterile Eppendorf microtubes and kept at $4{ }^{\circ} \mathrm{C}$. For C. sporogenes Pasteur 79.3, spore production was obtained using the Third Method described by Goldoni et al. (1980). 
Palmitic and oleic acids were obtained from Alfa Aesar (Strasbourg, France) and palmitoleic and stearic acid from Fluka and reported as being more than $96 \%, 90 \%, 95 \%$ and $97 \%$ pure respectively. Stock emulsions with different concentrations were obtained by mixing (Polytron ${ }^{\circledR}$ PT-MR 2100, Kinematica AG, Switzerland) and microsonication (Branson Sonifier 250, Branson Ultrasonics, USA) in distilled water with $0.1 \%$ Tween $^{\mathrm{TM}} 80$ as a dispersant. These solutions were added to a nutrient broth (Biokar Diagnostic BK003HA) for heating media or a nutrient broth with Bacteriological Agar (15g) (Biokar Diagnostic A1010HA) for recovery media. For the different FFA, the concentrations studied were lower than their critical micelle concentration values (Freeman 1969, Mukerjee and Mysels, 1971). The concentrations of free fatty acids added to the heating media were $0.8 \mathrm{mM}$ or $2 \mathrm{mM}$. In the recovery media, different concentrations were added from 0 to $2 \mathrm{mM}$ according to their critical micelle concentration values and their influence on the D values determined. After sterilization by autoclaving at $110^{\circ} \mathrm{C}$ for 45 minutes as described by Marounek et al. (2003), the $\mathrm{pH}$ was adjusted to 7 and the aw value was also regulated. For better visibility of bacterial communities, 2,3,5-Triphenyl-2H-Tetrazolium Chloride (TTC) was added to the recovery medium containing free fatty acids. Tween ${ }^{\mathrm{TM}} 80$ and TTC were obtained from Alfa Aesar (Strasbourg, France). The absence of influence of TTC and Tween ${ }^{\mathrm{TM}} 80$ on the bacterial heat resistance was checked (data not show).

\subsection{Spore heat treatments}

Firstly, $30 \mu \mathrm{l}$ of spore suspension was diluted in $3 \mathrm{ml}$ of adjusted heating medium. Capillary tubes of $200 \mu \mathrm{l}$ (vitrex) were filled with $100 \mu \mathrm{l}$ of sample, sealed, and subjected to a thermal treatment in a thermostated glycerol bath for different heating times. The heat treatment was stopped by cooling capillary tubes in a water/ice bath. Then they were broken at both ends and their contents poured into a tube containing $9 \mathrm{ml}$ of sterile tryptone salt broth (Biokar 
112 Diagnostics BK014HA) by rinsing with $0.9 \mathrm{ml}$ tryptone salt broth. The viable spores were

113 counted by duplicate plating in the recovery media and incubated $72 \mathrm{~h}$ at $37^{\circ} \mathrm{C}$ for $\mathrm{B}$. cereus

114 and C. sporogenes strains.

$116 \quad 2.4$ Experimental design and data analysis

117 For each heating and recovery media condition, classical D-values and their associated 118 standard deviation were estimated from survival kinetics. One concentration level was studied

119 to assess the influence of free fatty acids in heating media. Concerning the influence of free

120 fatty acids in recovery media, monofactorial design, without repeat, was carried out for each

121 acid studied. The influence of free fatty acid concentrations in recovery media on the D-

122 values was modelled by a simple Bigelow-like model as a secondary model (Eq1)

123

$\log D=\log D^{*}-\frac{[\text { acid }]}{Z_{F F A}^{\prime}}$

124 In this model $z_{\text {'FFA }}$ values correspond to an increase in free fatty acid concentrations in the

125 recovery media, leading to a 10 -fold reduction in the $\mathrm{D}$-value ( $\mathrm{D}^{*}$ corresponds to the $\mathrm{D}$ -

126 values without free fatty acids in recovery media). This parameter quantifies the influence of

127 fatty acid concentration in the recovery media on the heat resistance of bacterial spores.

128 The parameter values and their associated standard deviation were fitted using a non-linear

129 module ("nlinfit” and "nlparci” Matlab 6.1, The Mathworks). The "nlparci” function used to

130 assess standard deviation was based on the asymptotic normal distribution for the parameter

131 estimates (Bates and Watts, 1988).

132

133 Results

134 For the two species studied, B. cereus and $C$. sporogenes, most of the surviving cell kinetics

135 showed a linear relationship between heating time and the logarithm of survival cell numbers.

136 Hence bacterial heat resistance values were quantified using the classical D-values. 
137 Concerning heat treatment, D-values were determined in heating media in the presence of 4

138 free fatty acids (C16:0, C16:1, C18:0 and C18:1). Table 1 shows a low decrease in the D-

139 values when free fatty acids were added whatever the carbon chain length or number of chain

140 bonds for the two species studied.

141 The influence of free fatty acids in the recovery media on the apparent D-values was

142 determined for different concentrations of each acid type and for each strain studied. The

143 results are shown in Figures $1 \& 2$ and Tables $2 \&$ 3. Concerning D values determined in

144 media without fatty acid variability was observed. Bacterial spores coming from different

145 productions explain this variability. The presence of free fatty acids in recovery media greatly

146 reduced the apparent D-values for the two species studied. For the four free fatty acids

147 studied, the evolutions in the D-values according to their concentrations are presented Figure

148 3. A linear relationship is observed between free fatty acid concentration and log of D-values

149 for the 4 acids studied.

150 The $z_{\text {FFA }}$ values for the different acid types and for the two species studied are presented in

151 Table 4. The results presented in this table show that the presence of unsaturated free fatty

152 acids has a greater effect on D-values than saturated free fatty acids, with a greater sensitivity

153 for C. sporogenes Pasteur 79.3 compared to B. cereus NTCC 11145. During food heat 154 treatment, the environmental factors of heating and recovery media are identical. Table 5 155 presents the specific effects of palmitic and oleic acid in heating and recovery media on the

156 D-value of $B$. cereus spores and their associated effects in heating and in recovery media.

157 These results show the cumulative effect of free fatty acids during heat treatment and 158 recovery.

Discussion 
161 Free fatty acids in heating media enhance thermal inactivation of bacterial spores. The 162 influence of the free fatty acids studied (palmitic, palmitoleic, stearic and oleic acid) reduced 163 the D-value down to $30 \%$ for B. cereus and C. sporogenes. The D-values obtained appear 164 lower than those observed by Tremoulet et al. (2002) for G. stearothermophilus. For 0.5mM 165 of free fatty acid added to heating media, these authors observed D-value reduction ratios 166 ranging from 50\% to 75\% according to the acid type used. As shown by the results presented, the chain length or unsaturated bond does not appear to influence this moderate effect. To the best of our knowledge, the literature gives no information to explain the mechanism of free

169 fatty acid effects during heat treatment.

170 The benefit of the association of different stresses on bacterial inactivation has been described 171 by Leistner (2000) through the hurdle concept. The combination of heat treatment with 172 unfavourable environmental conditions of recovery media, low $\mathrm{pH}$ or aw, decreases the 173 apparent heat resistance of bacterial spores. During heat treatment, the proportion of dead and 174 injured spores increases with the heating time. In favourable and optimal environmental 175 recovery conditions, most injured bacterial cells survive and grow, thus D-values appear 176 higher. When recovery conditions are unfavourable, bacteria cells are stressed by the 177 environmental conditions, low $\mathrm{pH}$ or aw, resulting in growth inhibition followed by death. 178 Thus in unfavourable recovery conditions, D-values are lower than the D-values observed in 179 optimal recovery conditions. The influence of low $\mathrm{pH}$ or aw values of recovery media on the 180 apparent D-values has been quantified and modelled by Couvert et al. (1999) and Coroller et 181 al. (2001). Like these two environmental factors, free fatty acids in growth media represent a 182 stress for bacterial cell development and their presence in recovery media reduces the 183 apparent D-values. It can be noted that for the different free fatty acids studied, their concentrations were below the CMI values and did not modify the initial population size observed without heat treatment. Thus for the concentrations studied, free fatty acids added 
must be associated with a heat treatment or high thermal stress to show an inhibition activity.

187 Free fatty acids present in recovery media affect thermally injured bacteria. This observation was made by Ababouch et al. (1994) on B. cereus heat stressed cells for additions of stearic and oleic acid.

This effect of fatty acid concentration is described and quantified by a Bigelow-like model (Eq1) where the z'FFA parameter quantifies the impact of free fatty acid concentrations on the decrease in apparent heat resistance of bacterial spores. These effects of free fatty acids in recovery media have never been quantified in the literature. However $z_{\text {FFA }}$ values for different acids and for the two bacterial species studied can be compared to data concerning the impact of free fatty acid concentrations on bacteria spores or vegetative cells such as MIC 196 values.

197 The z' ${ }_{\text {FFA }}$ values for the saturated free fatty acids palmitic and stearic acid show a limited effect. This observation for stearic acid corresponds to the observation of Ababouch et al. (1994) on B. cereus unheated and heat-shocked spores. Concerning the Clostridium species, the high MIC values for palmitic and stearic acid, greater than $5 \mathrm{mM}$ for C. botulinum 201 (Skřivanova et al., 2005) and close to 10mM for C. perfringens (Kabara, 1978), concur with 202 our observation of a moderate influence of saturated fatty acid in recovery media to reduce D203 values. The impact of added unsaturated fatty acid on recovery media is higher than that of saturated fatty acid.

205 For the same carbon chain length, C18, the presence of unsaturated bonds in the carbon chain 206 decreased the $\mathrm{z}_{\mathrm{FFA}}$ from $3.19 \mathrm{mM}(\mathrm{C} 18: 0)$ to $0.89 \mathrm{mM}(\mathrm{C} 18: 1)$ for $B$. cereus and from $2072.36 \mathrm{mM}(\mathrm{C} 18: 0)$ to $0.36 \mathrm{mM}(\mathrm{C} 18: 1)$ for $C$. sporogenes. While no data is available in the 208 literature concerning the influence of these unsaturated free fatty acids in recovery media on 209 D-values, data exists for the MIC concentration concerning the impact of these acids on 210 Bacillus or Clostridium growth. The presence of unsaturated bonds in the carbon chain 
211 reduces the MIC values: $10 \mathrm{mM}$ (C18:0) to $0.75 \mathrm{mM}$ (C18:1) for G. stearothermophilus

212 (Tremoulet et al., 2002), $0.4 \mathrm{mM}$ to $0.05 \mathrm{mM}$ for B. megaterium (Galbraith et al., 1971)

213 11.4mM (C18:0) to 1.1mM (C18:1) for C. perfringens (Kabara, 1978) or 20mM (C18:0) to

214 0.48-1.48mM (C18:1) for C. perfringens (Skrivanova et al., 2005). For C16 chain length, the

215 influence of unsaturated bonds in the carbon chain on the decrease in z' ${ }_{\text {FFA }}$ values was also

216 observed. This observation concurs with the difference in MIC values determined by

217 Tremoulet et al. (2002): 10mM for palmitic acid, C16:0, and 1.25mM for palmitoleic acid,

218 C16:1, for G. stearothermophilus strain. For these acids, similar observations were presented

219 by Kabara et al. (1972) for different bacterial species such as Streptococcus or Pneumococcus.

220 The presence of long chain free fatty acids, particularly unsaturated free fatty acids, in

221 recovery media creates unfavourable conditions for the growth of injured heat-treated spores.

222 Different mechanisms affect the physiology of bacterial spores or vegetative cells.

223 High adsorption of free fatty acids onto bacteria was observed by Maxcy and Dill (1967) and

224 Galbraith and Miller (1973a). The accumulation of free fatty acids on the cell or spore surface

225 is the first stage of the inhibition mechanism (Nieman 1954). Concerning bacterial spores,

226 Foster and Wynne (1948) observed an inhibition of germination of C. botulinum spores in the

227 presence of oleic acid. In 1982, Yasuda et al. assessed the inhibitory activity of short and long

228 chain fatty acids on spore germination. The percentage inhibition of unsaturated oleic acid is

229 higher than saturated fatty acids which present the same effect. These authors suggest that

230 hydrophilic environments inhibit L-alanine receptors, keys to germination mechanisms

231 described by Johnstone in 1994.

232 The difference in solubility of saturated and unsaturated fatty acids may explain the higher

233 inhibitory effect of unsaturated fatty acids. In addition to germination inhibition, free fatty

234 acids have long been recognized as growth inhibitors for Gram-positive bacteria (Kabara,

235 1978). Ababouch et al. (1994) studied the influence of stearic and oleic acids both on spore 
and vegetative cells of $B$. cereus growth. For acid-treated spore or vegetative bacteria, morphological modifications appeared, giving long thin cells. Knapp and Melly (1986) made the same observations for Staphylococcus aureus in the presence of arachidonic acid. The influence of higher concentrations of free fatty acids in growth media causes membrane disruption and cell lysis (Tsuchido et al., 1992). Zheng et al. (2005) demonstrated specific 241 action of palmitoleic and oleic acid on enol-acyl carrier protein reductase (Fab1) which 242 inhibits fatty acid synthesis for S. aureus and Escherichia coli. Stearic acid does not present 243 this effect.

244 Galbraith and Miller (1973b) showed that for Bacillus megaterium cells, low concentrations 245 of fatty acids stimulate oxygen uptake, whereas high concentrations (0.2mM) of oleic acid 246 inhibit oxygen intake. These authors observed that unsaturated fatty acids were more active 247 than saturated acids. A similar decrease or inhibition of nutrient uptake was observed for 248 amino acids glutamic acid and lysine for B. megaterium and C. perfringens vegetative cells 249 (Galbraith and Miller, 1973b) and glucose and glycerol uptake for Brochothrix thermosphacta 250 (Macaskie, 1982).

251 All these effects of free fatty acids on unheated bacteria were enhanced by the injury caused 252 by heat treatment. Free fatty acids are present in natural oils such as olive oil or in fish and 253 animal fats, for instance in canned fat duck liver. Thus the additive influences of free fatty 254 acids in heating and particularly in recovery media can be taken into account to safely reduce 255 heat treatment of bacterial spores. These major reductions in thermal resistance by fatty acids 256 in recovery media may explain the sterility of canned fat duck liver which is heat treated with 257 very low sterilization values, lower than 1 . According to our results, the high concentrations 258 of free fatty acids in fresh fat duck liver, $33.3 \mathrm{mM}$ of oleic acid and $2.4 \mathrm{mM}$ of palmitoleic acid 259 (Tremoulet et al., 2002), are sufficient to greatly reduce the apparent heat resistance of 260 bacterial spores. With these acid concentrations, the D-value calculated using equation 1 is 
261 theoretically reduced by a factor of $10^{33}$ with oleic acid concentrations (33.3mM) and by a 262 factor of $3 * 10^{10}$ with palmitoleic acid concentrations (2.4mM) for B. cereus NTCC11145 263 spores. The presence of free fatty acids in food associated with a heat treatment may be used 264 to reduce heat treatment or increase food safety.

266 Acknowledgments

267 The authors would like to thank the Ministry of Research and Higher Education of Gabon for 268 the internship conducted during the author's doctoral $\mathrm{PhD}$ study.

269

270 
272 Ababouch, H.L., Bouquartacha, F., Busta, F.F., 1994. Inhibition of Bacillus cereus spores and 273 vegetative cells by fatty acids and glyceryl monododecanoate. Food Microbiology 11, 327274336.

275 Blackburn C. de W., Curtis L.M., Humpheson L., Billon C., McClure, P.J., 1997. 276 Development of thermal inactivation models for Salmonella enteritidis and Escherichia coli 277 O157:H7 with temperature, $\mathrm{pH}$ and $\mathrm{NaCl}$ as controlling factors. International Journal of Food 278 Microbiology 38, 31-44.

279 Coroller, L., Leguérinel, I., Mafart, P., 2001. Effect of the water activities of heating and 280 recovery media on apparent heat resistance of Bacillus cereus spores. Journal of Applied and 281 Environmental Microbiology 67, 317-322.

282 Couvert, O., Leguérinel, I., Mafart, P., 1999. Modelling the overall effect of pH on the 283 apparent heat resistance of Bacillus cereus spores. International Journal of Food Microbiology 284 49, 57-62.

Davey, K.R., 1993. Linear-Arrhenius models for bacterial growth and death and vitamin 286 denaturations. Journal of Industrial Microbiology and Biotechnology 12, 172-179.

287 Foster, J.W., Wynne, E.S., 1948. Physical studies on spore germination, with special 288 reference to Clostridium botulinum, IV Inhibition of germination by unsaturated C18 fatty 289 acids. Journal of Bacteriology 55, 495-504.

290 Freeman C.P. 1969. Properties of fatty acids in dispersions of emulsified lipid and bile salt 291 and the significance of these properties in fat absorption in the pig and the sheep. British 292 Journal of Nutrition 23, 249-263.

293 Galbraith, H., Miller, T.B., Paton, A.M., Thompson, J.K., 1971. Antibacterial activity of long 294 chain fatty acids and the reversal with calcium, magnesium, ergocalciferol and cholesterol. 295 Journal of Applied Bacteriology 34, 803-813. 
296 Galbraith, H., Miller, T.B., 1973a. Physicochemical effects of long chain fatty acids on 297 bacterial cells and their protoplasts. Journal of Applied Bacteriology 36, 647-658.

298 Galbraith, H., Miller, T.B., 1973b. Effect of long chain fatty acids on bacterial respiration and 299 amino acid uptake. Journal of Applied Bacteriology 36, 659-675.

300 Goldoni, J.S., Kojima, S., Leonard, S., Heil, J.R., 1980. Growing spores of P. A. 3679 in 301 formulations of beef heart infusion broth. Journal of Food Science 45, 467-470.

302 Grecz, N., Wagenar, R.O., Dack, C.M., 1959. Relation of fatty acids to inhibition of 303 Clostridium botulinum in aged surface ripened cheese. Applied Microbiology 7, 228-234.

304 Johnstone, K., 1994. The trigger mechanism of spore germination: current concepts. Journal 305 of Applied Bacteriology 76, 17S-24S.

306 Juneja, V.K., Eblen, B.S., 1999. Predictive thermal inactivation model for Listeria 307 monocytogenes with temperature, $\mathrm{pH}, \mathrm{NaCl}$, and sodium pyrophosphate as controlling factors. 308 Journal of Food Protection 62, 986-993.

309 Kabara, J.J., Swieczkowski, D.M., Conley, A.J., Truant, J.P., 1972. Fatty Acids and 310 Derivatives as Antimicrobial Agents. Antimicrobial Agents and Chemotherapy 2, 23-28.

311 Kabara, J.J., 1978. Fatty acids and derivatives as antimicrobial agents. A review. In: Kabara, 312 J.J. (Ed), The Pharmacological Effect of Lipids, Volume I. American Oil Chemists Society, 313 Champaign, III, pp.1-14.

314 Knapp, R.H., Melly, M.A., 1986. Bacterial effect of polyunsaturated fatty acids. The Journal 315 of Infectious Diseases 154, 84-94.

316 Lee, J.Y., Kim, Y.S., Shin, D.H., 2002. Antimicrobial synergistic effect of linolenic acid and 317 monoglyceride against Bacillus cereus and Staphylococcus aureus. Journal of Food 318 Chemistry 50, 2193-2199. 
Leguerinel, I., Spegagne, I., Couvert, O., Gaillard, S., Mafart, P., 2005. Validation of an

320 overall model describing the effect of three environmental factors on the apparent D-value of

321 Bacillus cereus spores. International Journal of Food Microbiology 100, 223-229.

322 Leistner, L., 2000. Basic aspects of food preservation by hurdle technology. International 323 Journal of Food Microbiology 55, 181-186.

324 Macaskie, L.E., 1982. Inhibition of growth of Brochothrix thermosphacta by palmitic acid. 325 Journal of Applied Microbiology 52, 339 - 343.

326 Marounek, M., Skřivanova, E., Rada, V., 2003. Susceptibility of Escherichia coli to C2-C18

327 fatty acids. Folia Microbiologica 48, 731-735.

328 Maxcy, R.B., Dill, C.W., 1967. Adsorption of free fatty acids on cells of certain 329 microorganisms. Journal of Dairy Science 50, 472-476.

330 Mukerjee, P., and Mysels, K. J., 1971. National Standards Reference Data Series. Vol. 36.

331 National Bureau of Standards.

332 Nieman, C., 1954. Influence of trace amounts of fatty acids on the growth of microorganisms.

333 Bacteriology Review 18, 147-163.

334 Skřivanova, E., Marounek, M., Dlouhá, G., Kañka J., 2005. Susceptibility of Clostridium 335 Perfringens to C2-C18 fatty acids. Letters in Applied Microbiology 41, 77-81.

336 Tremoulet, F., Rabier, P., Gas, G., 2002. Inhibition of Bacillus stearothermophilus spores in 337 liquid medium by free fatty acids with and without heat: possible mechanism for the 338 microbiological stability of canned fat-duck liver. Journal of Food Sciences 67, 1144-1148.

339 Tsuchido, T., Naruki, S., Shibasaki, I., 1992. Inhibition of Bacillus subtilis var. niger spores 340 by fatty acids and their monoglycerides. Journal of Antibacterial and Antifungal Agents 20, $341 \quad 197-203$. 
342 Yasuda, Y, Tochikubo, K., Hachisuka, Y., Tomida, H., Ikeda, K., 1982. Quantitative

343 structure-inhibitory activity relationships of phenols and fatty acids for Bacillus subtilis spore

344 germination. Journal of Medical Chemistry 25, 315-320.

345 Zheng, C.J., Yoo, J.S., Lee, T.G., Cho H.Y., Kim Y.H., Kim, W.G., 2005. Fatty acids

346 synthesis is a target for antibacterial activity of unsaturated fatty acids. FEBS Letters 579, 347 5157-6162.

348

349 
Titles of figures and tables

351 Figure 1: Log N (colony-forming units, cfu) vs. time (min) for Bacillus cereus NTCC 11145

352 to $100^{\circ} \mathrm{C}$ (A \& C) and Clostridium sporogenes Pasteur 79.3 to $90^{\circ} \mathrm{C}$ (B \& D) with, in 353 recovery media, different concentrations of palmitic acid (A \& B) or stearic acid (C \& D) at 354 different concentrations: $0 \mathrm{mM} \odot, 0.2 \mathrm{mM} \square, 0.4 \mathrm{mM} \boldsymbol{\Delta},(\mathrm{C} 18: 1) 0.6 \mathrm{mM} \nabla, 0.8 \mathrm{mM} \bullet$ $3551 \mathrm{mM} \bigcirc, 1.5 \mathrm{mM} \mathbf{\square}, 2 \mathrm{mM} \triangle$.

356

357 Figure 2: Log N (colony-forming units, cfu) vs. time (min) for Bacillus cereus NTCC 11145 358 heated to $100^{\circ} \mathrm{C}$ (A \& C) and Clostridium sporogenes Pasteur 79.3 heated to $90^{\circ} \mathrm{C}$ (B \& D) 359 with, in recovery media, different concentrations of palmitoleic acid (A \& B) or oleic acid (C 360 \& D) at different concentrations: $0 \mathrm{mM} \bullet, 0.05 \mathrm{mM} \square, 0.1 \mathrm{mM} \boldsymbol{\Lambda}, 0.2 \mathrm{mM} \diamond, 0.4 \mathrm{mM} \bigcirc$, $3610.6 \mathrm{mM} \square, 0.8 \mathrm{mM} \triangle$.

362

363 Figure 3: Log D (minutes) vs. FFA concentration $(\mu \mathrm{M})$ with respectively palmitic

364 palmitoleic $\bigcirc$, stearic $\boldsymbol{\Delta}$ and oleic $\triangle$ acid in recovery medium for: spores Bacillus cereus

365 NTCC 11145 heated to $100^{\circ} \mathrm{C}$ (A) and Clostridium sporogenes Pasteur 79.3 heated to $90^{\circ} \mathrm{C}$ 366 (B). 
369 Table 1: D-values (minutes) for Bacillus cereus NTCC 11145 heated to $100^{\circ} \mathrm{C}$ and

370 Clostridium sporogenes Pasteur 79.3 heated to $90^{\circ} \mathrm{C}$ with palmitic, palmitoleic, stearic and

371 oleic acids in heating medium.

372

373 Table 2: D-values (minutes) for Bacillus cereus NTCC 11145 heated to $100^{\circ} \mathrm{C}$ in the presence

374 of different concentrations of palmitic, palmitoleic, stearic and oleic acid in recovery medium.

375

376 Table 3: D-values (minutes) for Clostridium sporogenes Pasteur 79.3 heated to $90^{\circ} \mathrm{C}$ in the

377 presence of different concentrations of palmitic, palmitoleic, stearic and oleic acid in recovery 378 medium.

380 Table 4: z-values for palmitic, palmitoleic, stearic and oleic acids in recovery medium for Bacillus cereus NTCC 11145 and Clostridium sporogenes Pasteur 79.3.

382

383 Table 5: Specific effect of the addition of $0.8 \mathrm{mM}$ of palmitic and oleic acid in heating and 384 recovery media on the D-value of Bacillus cereus spores heated at $100^{\circ} \mathrm{C}$ and their associated 385 effect in heating and recovery media. 

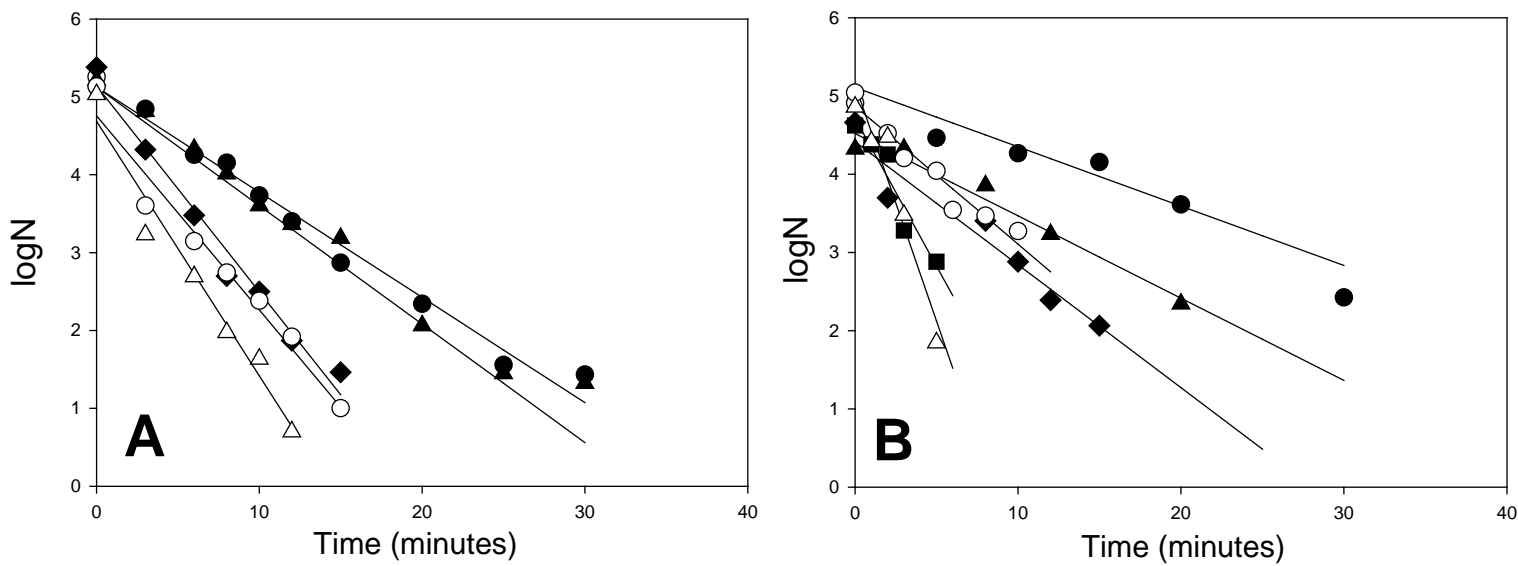

387
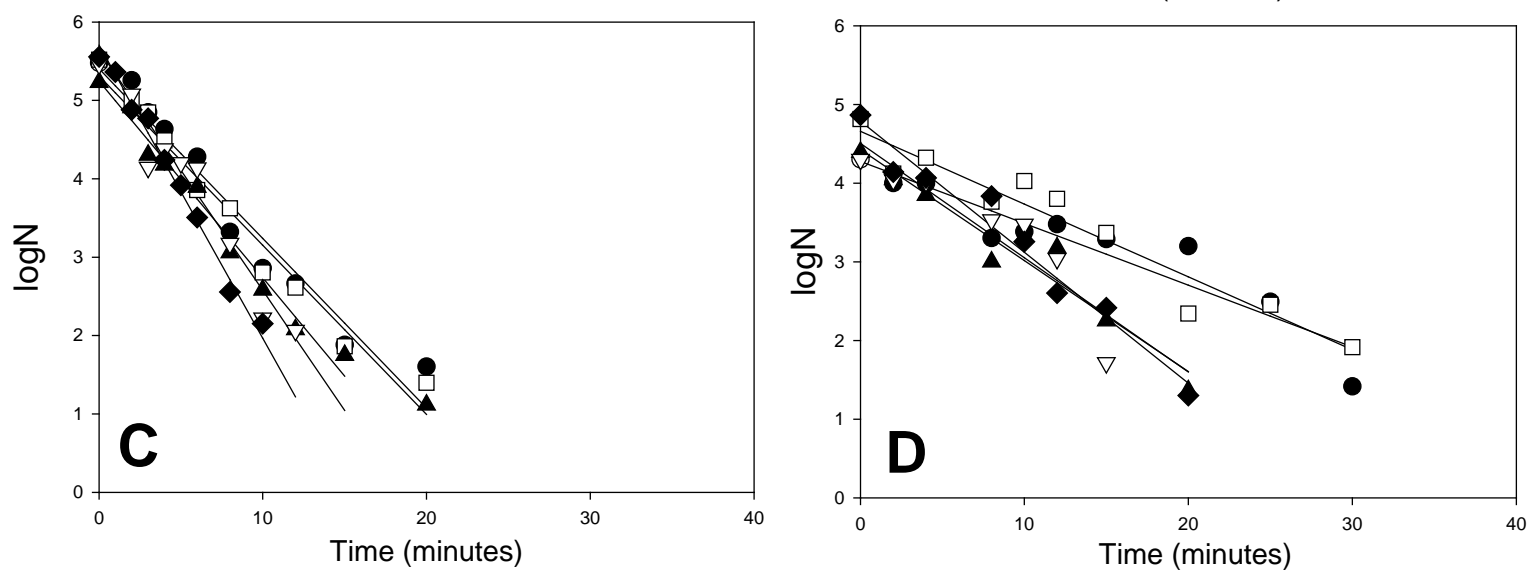

388

389

$390 \quad$ Figure 1

391

392

393 

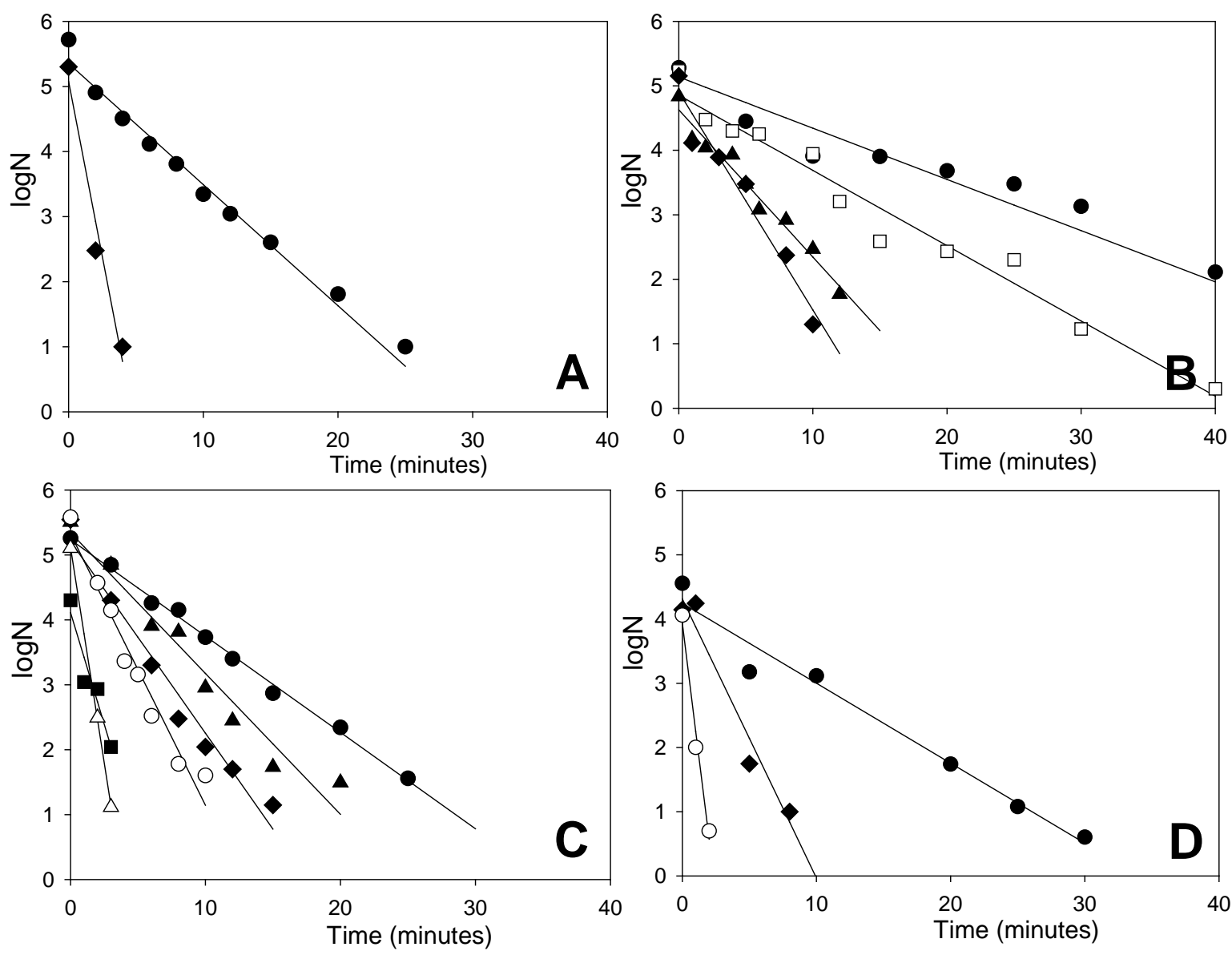

Figure 2 

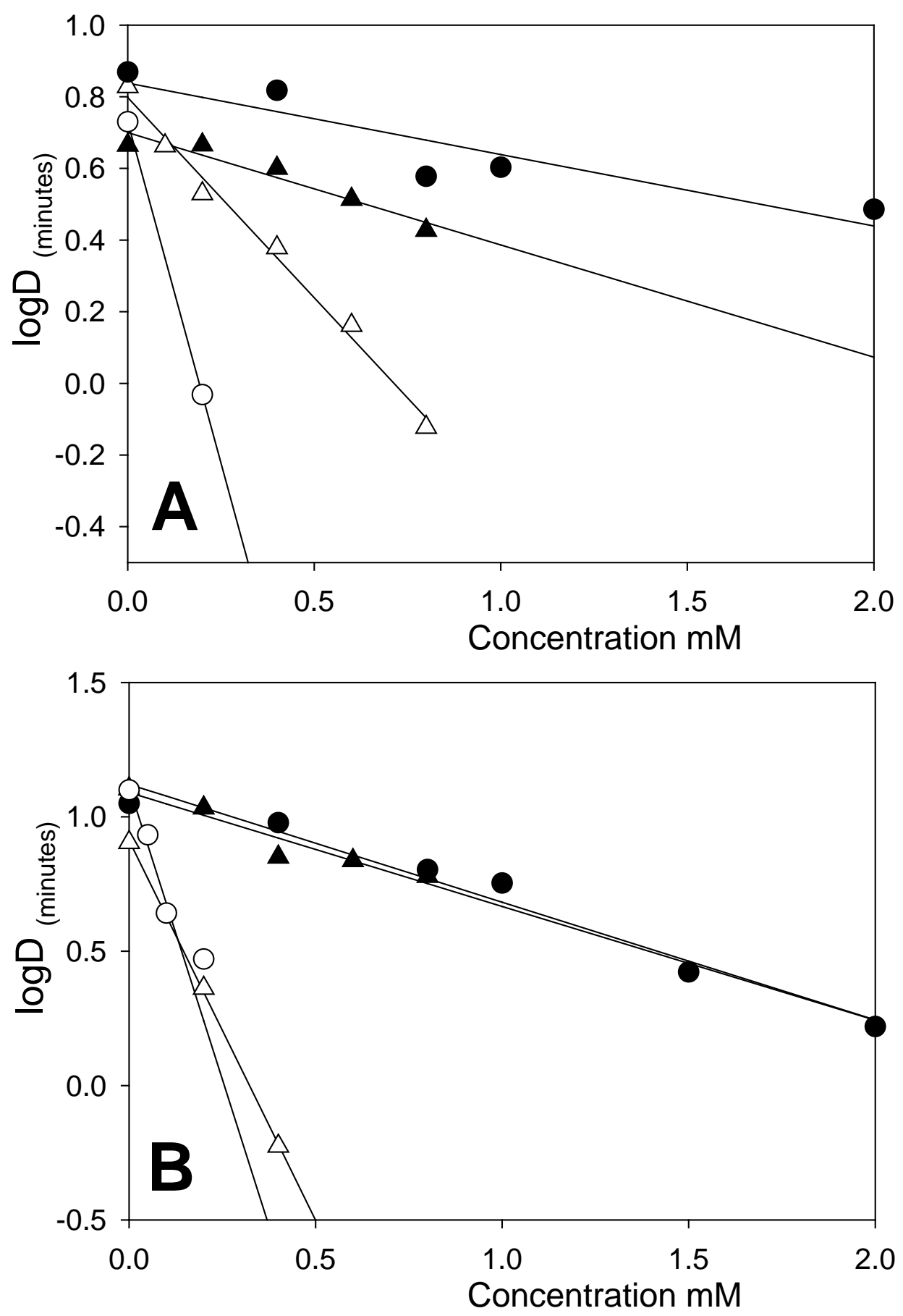

400

401 Figure $3 \mathrm{~A} \& \mathrm{~B}$

402 


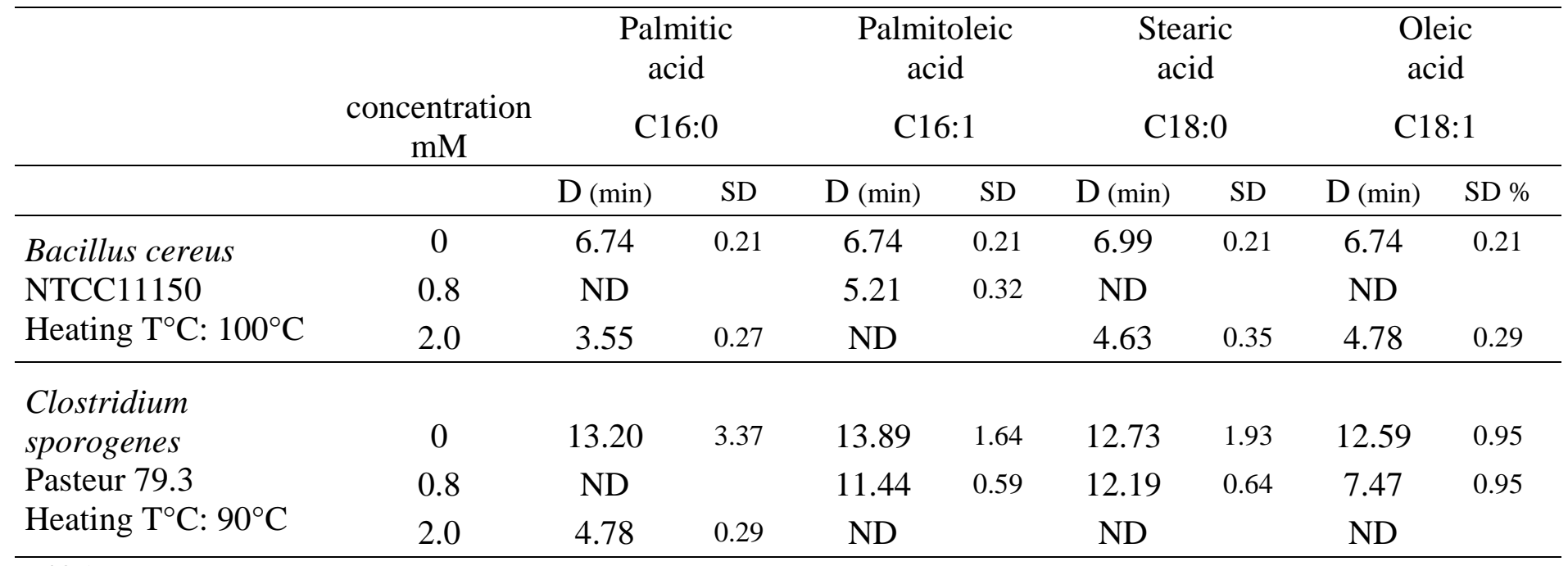

405

406

407

408 Table 1

409

410

411

412

413 
414

\begin{tabular}{|c|c|c|c|c|c|c|c|c|}
\hline \multirow{2}{*}{$\begin{array}{c}\text { Concentration } \\
\mu \mathrm{M}\end{array}$} & \multicolumn{2}{|c|}{$\begin{array}{l}\text { Palmitic acid } \\
\text { C16:0 }\end{array}$} & \multicolumn{2}{|c|}{$\begin{array}{l}\text { Palmitoleic acid } \\
\text { C16:1 }\end{array}$} & \multicolumn{2}{|c|}{$\begin{array}{l}\text { Stearic acid } \\
\text { C18:0 }\end{array}$} & \multicolumn{2}{|c|}{$\begin{array}{l}\text { Oleic acid } \\
\text { C18:1 }\end{array}$} \\
\hline & $\begin{array}{c}\mathrm{D}_{100^{\circ} \mathrm{C}} \\
\text { (min) }\end{array}$ & SD & $\begin{array}{l}\mathrm{D}_{100^{\circ} \mathrm{C}} \\
\text { (min) }\end{array}$ & SD & $\begin{array}{c}\mathrm{D}_{100^{\circ} \mathrm{C}} \\
\text { (min) }\end{array}$ & $\mathrm{SD}$ & $\begin{array}{l}\mathrm{D}_{100^{\circ} \mathrm{C}} \\
\text { (min) }\end{array}$ & SD \\
\hline 0 & 7.40 & 0.42 & 5.37 & 0.35 & 4.62 & 0.47 & 6.74 & 0.72 \\
\hline 0.1 & ND & & ND & & ND & & 4.61 & 0.49 \\
\hline 0.2 & ND & & 0.93 & 1.09 & 4.63 & 0.35 & 3.38 & 0.35 \\
\hline 0.4 & 6.57 & 0.26 & & & 3.99 & 0.28 & 2.39 & 0.24 \\
\hline 0.6 & ND & & & & 3.26 & 0.28 & 1.45 & 0.69 \\
\hline 0.8 & 3.78 & 0.34 & & & 2.68 & 0.16 & 0.75 & 0.07 \\
\hline 1.0 & 4.01 & 0.44 & & & & & & \\
\hline 1.5 & ND & & & & & & & \\
\hline 2.0 & 3.06 & 0.70 & & & & & & \\
\hline
\end{tabular}

415

416 Table 2

417

418 


\begin{tabular}{|c|c|c|c|c|c|c|c|c|}
\hline \multirow[t]{2}{*}{$\begin{array}{c}\text { Concentration } \\
\mu \mathrm{M} \\
\end{array}$} & \multicolumn{2}{|c|}{$\begin{array}{l}\text { Palmitic acid } \\
\text { C16:0 }\end{array}$} & \multicolumn{2}{|c|}{$\begin{array}{l}\text { Palmitoleic acid } \\
\qquad \text { C16:1 }\end{array}$} & \multicolumn{2}{|c|}{$\begin{array}{c}\text { Stearic acid } \\
\text { C18:0 }\end{array}$} & \multicolumn{2}{|c|}{$\begin{array}{l}\text { Oleic acid } \\
\text { C18:1 }\end{array}$} \\
\hline & $\begin{array}{l}\mathrm{D}_{90^{\circ} \mathrm{C}} \\
\text { (min) }\end{array}$ & $\mathrm{SD}$ & $\begin{array}{l}\mathrm{D}_{90^{\circ} \mathrm{C}} \\
\text { (min) }\end{array}$ & SD & $\begin{array}{l}\mathrm{D}_{90^{\circ} \mathrm{C}} \\
\text { (min) }\end{array}$ & SD & $\begin{array}{l}\mathrm{D}_{90^{\circ} \mathrm{C}} \\
\text { (min) }\end{array}$ & SD \\
\hline 0 & 11.22 & 2.27 & 12.59 & 0.95 & 12.73 & 1.93 & 8.03 & 0.98 \\
\hline 0.05 & ND & & 8.57 & 0.61 & ND & & ND & \\
\hline 0.1 & ND & & 4.38 & 0.36 & ND & & ND & \\
\hline 0.2 & ND & & 2.95 & 0.45 & 10.81 & 1.22 & 2.30 & 0.34 \\
\hline 0.4 & 9.51 & 1.61 & & & 7.09 & 0.96 & 0.59 & 0.51 \\
\hline 0.6 & ND & & & & 6.88 & 1.78 & & \\
\hline 0.8 & 6.36 & 1.21 & & & 6.01 & 0.60 & & \\
\hline 1.0 & 5.67 & 0.86 & & & & & & \\
\hline 1.5 & 2.65 & 0.74 & & & & & & \\
\hline 2.0 & 1.66 & 0.46 & & & & & & \\
\hline
\end{tabular}

420

421 Table 3

422 
423

\begin{tabular}{|c|c|c|c|c|c|c|c|c|}
\hline & \multicolumn{2}{|c|}{$\begin{array}{l}\text { Palmitic acid } \\
\text { C16:0 }\end{array}$} & \multicolumn{2}{|c|}{$\begin{array}{c}\text { Palmitoleic acid } \\
\text { C16:1 }\end{array}$} & \multicolumn{2}{|c|}{$\begin{array}{l}\text { Stearic acid } \\
\text { C18:0 }\end{array}$} & \multicolumn{2}{|c|}{$\begin{array}{l}\text { Oleic acid } \\
\text { C18:1 }\end{array}$} \\
\hline & $\mathrm{z}^{\prime} \mathrm{mM}$ & SD & $\mathrm{z}^{\prime} \mathrm{mM}$ & SD & $\mathrm{z}^{\prime} \mathrm{mM}$ & SD & $\mathrm{z}^{\prime} \mathrm{mM}$ & $\mathrm{SD}$ \\
\hline $\begin{array}{l}\text { Bacillus cereus } \\
\text { NTCC11145 }\end{array}$ & 5.01 & 2.10 & 0.26 & - & 3.19 & 0.85 & 0.89 & 0.7 \\
\hline $\begin{array}{c}\text { Clostridium sporogenes } \\
\text { Pasteur } 79.3\end{array}$ & 2.28 & 0.27 & 0.23 & 0.04 & 2.36 & 0.68 & 0.36 & 0.5 \\
\hline
\end{tabular}

424

425

426 Table 4

427

428 


\begin{tabular}{|c|c|c|c|c|}
\hline & \multicolumn{2}{|c|}{$\begin{array}{l}\text { Palmitic acid } \\
2 \mathrm{mM}\end{array}$} & \multicolumn{2}{|c|}{$\begin{array}{c}\text { Oleic acid } \\
0.8 \mathrm{mM}\end{array}$} \\
\hline & $\mathrm{D}_{100^{\circ} \mathrm{C}}(\mathrm{min})$ & SD & $\mathrm{D}_{100^{\circ} \mathrm{C}}(\mathrm{min})$ & SD \\
\hline No fatty acid added to media & $6.90^{(\mathrm{a})}$ & 0.23 & $6.90^{(\mathrm{a})}$ & 0.23 \\
\hline Fatty acid added to heating media & $3.48^{(b)}$ & 0.18 & $4.32^{(\mathrm{b})}$ & 0.26 \\
\hline Fatty acid added to recovery media & $2.04^{\text {(c) }}$ & 0.15 & $0.98^{(\mathrm{c})}$ & 0.14 \\
\hline Fatty acid added to both heating and recovery media & 1.77 & 0.16 & 0.66 & 0.06 \\
\hline $\begin{array}{l}\text { "Theoretical" or predicted value taking account D } \\
\text { values (a), (b) and (c) }\end{array}$ & 1.07 & & 0.61 & \\
\hline $\begin{array}{l}\text { "Theoretical” or predicted value taking account } \mathrm{D} \\
\text { values from Tables } 1 \text { and } \mathrm{z}_{\text {FFA }} \text { values from table } 4\end{array}$ & 1.45 & & 0.75 & \\
\hline
\end{tabular}

430

$431 \quad$ Table 5

432

433 
435

436 